\title{
Soft Law Possibilities in Global Health Law
}

\section{Global Health Law}

\author{
Sharifah Sekalala \\ and Haleema Masud
}

Keywords: Soft Law, Global Health Law, Global Health Governance, International Health Regulations, COVID-19

\section{Introduction}

The COVID-19 crisis has reignited questions about the centrality of law in stemming the spread of infectious diseases. There are questions about whether new laws can enable greater international collaboration, collective action and shared responsibility and accountability for new global health threats. In addressing these global health threats, it will be necessary to look to global health law, reflecting "the study and practice of international law that shapes norms and processes and institutions to create the conditions for people throughout the world to attain the highest possible level of physical and mental health."1 These sources of global health law have been categorized under international law into hard law (e.g., treaties that bind states) and soft law (e.g., codes of practice negotiated by states). ${ }^{2}$

This column examines the central importance of soft law in developing and implementing global health law. Beginning by situating the role of hard and soft law in the frameworks of the World Health Organization (WHO), this column illustrates the centrality of soft law in global health law governance. The column then looks to the potential application of soft law in resolving some of the wider questions of infectious disease control in the wake of the COVID19 crisis, concluding that soft law is complementary to the hard law, as it offers a flexible way to mobilize the consent and commitment of states in a rapidly changing global health environment.

\section{Hard Law and Soft Law in Global Health}

Although hard law is binding and soft law is not, the distinction is actually more nuanced. Legal norms are not binary, but are based on graduated normativity, from binding to nonbinding. ${ }^{3}$ Global health law ranges from binding treaties and norms (e.g., those encompassed in the right to health and other human rights norms codified under international law) to authoritative yet non-binding normative instruments, such as resolutions, declarations, guidelines, protocols, and recommendations. The implementation of both hard and soft law may rely on policy recommendations which need not have any normative content at all.

The Constitution of the World Health Organization (WHO) grants the World Health Assembly considerable powers to develop global health law. ${ }^{4}$ Yet, in its history, the WHO has developed only two treaties: the Framework Convention on Tobacco Control (FCTC) and the International Health Regulations (IHR), and many scholars believe that the WHO should have used its lawmaking authority to agree to more binding law to address global health problems. ${ }^{5}$ The WHO has struggled to fulfill its mandate to develop global health law for three main reasons. Firstly, many global health issues are highly complex and highly interdependent with other international law regimes, such as trade and the environment, which makes it difficult for the WHO to gain international agreement in the World

Sharifah Sekalala, Ph.D., L.L.M., L.L.B., is an Associate Professor in the Law School at the University of Warwick. Haleema Masud is a Ph.D. Researcher at Warwick Medical School, University of Warwick. 
Health Assembly. Secondly, global health outcomes are increasingly determined by non-state actors, such as corporations, which are outside of the direct scope of WHO governance. Thirdly, as seen in the two treaties that the WHO has developed, it is not always easy for the WHO to catalyze state implementation.

The FCTC entered into force in 2005 , creating legally binding norms to reduce the demand for and supply of tobacco, with information sharing to achieve tobacco control globally. The FCTC is often viewed as a momentous achievement; however, the treaty took over a decade to negotiate, with a politically contentious process in which states struggled to rein in the power of Big Tobacco, which lobbied state representatives in an effort to prevent FCTC adoption. Despite its success, the treaty has two major weaknesses: First, it contains ambiguous language, which allows countries broad discretion in interpreting treaty provisions, leading to inconsistent implementation. Second, it does not provide resources to low- and middle-income countries to support implementation of the FCTC. Big Tobacco has continued to fight back against the FCTC, bringing cases under multiple international law regimes, such as the World Trade Organization and investment treaties, to prevent states from adopting tobacco-control legislation. ${ }^{6}$

Likewise, the IHR, which aims to prevent, protect, and control the spread of infectious diseases, took ten years to negotiate and has been critiqued for its ambiguity with regards to the notification system, lack of certainty about the circumstances under which diseases are declared a Public Health Emergency of International Concern, and above all for its lack of accountability for violations. For instance, countries have often failed to inform the WHO when facing a disease outbreak, have remained unprepared to respond to public health emergencies in line with their IHR obligations, and have rejected specific WHO advice in the emergency response, instituting additional measures such as border closures in violation of their human rights obliga- tions. ${ }^{7}$ Without accountability under global health law, states have not complied with key provisions that are set out by the IHR, thereby leading to the spread of infectious diseases. ${ }^{8}$

\section{The Benefits of Soft Law}

Looking beyond these treaties, the WHO has been very successful at using soft law for global health governance: to regulate issues such as unhealthy food and diets, give normative clarification to treaties, set standards, ensure monitoring and accountability, and serve as precursor to hard law, especially when the science is still uncertain or there is a lack of political consensus. allowed countries to prioritize access to medicines as part of the right to health over the rights of intellectual property, thereby ensuring access to generic medicines.

Additionally, soft law can also form a basis for hard law, especially in highly technical areas, or where states need political space for consensus building. The FCTC was agreed in 2003 after a series of 17 non-binding resolutions on tobacco control were passed between 1970 and 1988 by the World Health Assembly, and built upon the 1998 establishment of the WHO Tobacco Free Initiative.

Nevertheless, soft law does have limitations. If not backed by an

\section{This column examines the central importance of soft law in developing and implementing global health law. Beginning by situating the role of hard and soft law in the frameworks of the World Health Organization (WHO), this column illustrates the centrality of soft law in global health law governance. The column then looks to the potential application of soft law in resolving some of the wider questions of infectious disease control in the wake of the COVID-19 crisis, concluding that soft law is complementary to the hard law, as it offers a flexible way to mobilize the consent and commitment of states in a rapidly changing global health environment.}

Soft laws have grown within the WHO framework because they are easy and quick for states to adopt. Their non-binding nature can help achieve consensus in difficult areas where different countries have different interests but also where the commercial interests of private actors are involved. For instance, in the Doha Declaration on the TRIPS Agreement and Public Health, soft law was used to clarify which norms trumped others when there was a clash between the competing regimes of international trade law and global health law. ${ }^{9}$ This soft law agreement authoritative body, soft law may lack the binding obligations necessary to motivate states to act. For example, the WHO's Global Code of Practice on the International Recruitment of Health Personnel has had little effect on domestic policies and practices because it has ambiguous provisions without binding obligations to prevent the recruitment of essential health personnel across countries. ${ }^{10}$

Another disadvantage of soft law is that organizations that rely on it may be perceived as weak. For example, if the WHO acts principally through non-binding agreements, while other 
sectors develop hard law, this may prevent the WHO from being seen as an authoritative international actor, ${ }^{11}$ which could cause states to skew their regulatory preferences toward areas in which they may face accountability for non-compliance, causing a regulatory chill in public health regulation..$^{2}$ However, there is evidence that states are agreeing to fewer hard law treaties over time, which means that, for the moment, soft law remains the most plausible way to frame global governance. $^{13}$

In strengthening soft law, indicators provide a path to evaluate progress and promote accountability. For instance, the Office of the High Commissioner for Human Rights has developed human rights indicators to monitor human rights structures, processes and outcomes as a way of evaluating human rights implementation across countries. ${ }^{14}$ Similarly, UNAIDS uses a series of indicators that arise out of the UN Political Declarations on AIDS in order to measure how countries are responding to the AIDS pandemic. ${ }^{15}$ Soft law thus brokers compliance through monitoring and review to facilitate accountability for compliance with international agreements.

\section{Reimagining Soft Law in the Wake of the COVID-19 Crisis}

The current COVID-19 pandemic has shown that global health law is critical in responding to infectious diseases, with four specific possibilities for soft law to address the pandemic:

1. Clarification of State Obligations The WHO could use soft law to clarify and reinforce technical guidance in areas such as contact tracing, testing, treatment, and public health responses. While much of this guidance has been technical, there is scope for this guidance to become normative if it reinforces existing legal norms, facilitating state compliance with the law.

\section{Soft Law Amendments to the IHR} Although the WHO has played a critical role in global health gover- nance, there is uncertainty about its role in a post-pandemic world. Scholars have identified a number of weaknesses in the IHR. ${ }^{16}$ There have been calls to give the IHR wider-ranging enforcement powers, involve more private sector actors, and expand its core mandate. ${ }^{17}$ However, current geopolitical tensions also make it difficult to revise the IHR. Soft law might provide a way forward. ${ }^{18}$

\section{Normative Guidance}

The WHO could use soft law to further normative guidance in areas such as the relationship between the IHR and human rights. Human rights have a strong textual foundation in the revised IHR (2005), both as a protection against measures that unnecessarily interfere with individual liberties and for interpreting and implementing every aspect of the IHR, notably the right to health..$^{19}$ The COVID-19 crisis has highlighted the need for more normative guidance within the context of human rights: for instance, large-scale quarantines, discrimination against vulnerable groups, increased digital surveillance, and access to vaccines. For instance, the existence of the COVAX facility to finance vaccines for people in the developing world could be strengthened if the WHO gave some normative guidance on international obligations of "solidarity" as part of the essential fulfillment of the right to health.

\section{Better Enforcement Mechanisms} Previously, the WHO used soft law to enable accountability. For instance, when Indonesia refused to share its samples of the avian flu virus, because it feared that it would not get a fair share of the resulting scientific discoveries, the WHO PIP Framework (a soft law instrument developed under the
WHO) was created to incorporate benefit sharing for countries, including both monetary and inkind benefits. ${ }^{20}$ There have been several suggestions about how the WHO could use soft law to improve enforcement, including by creating a forum that would try to ease political tensions through sharing and discussing national risk assessments, mediating informally between states, and enabling greater coordination in the response to infectious diseases. ${ }^{21}$ The WHO Director General has also proposed a system of universal periodic review, in which countries agree to a regular and transparent review of each nation's preparedness. ${ }^{22}$

\section{Conclusion}

Global health law is largely constituted through soft law, and soft law needs to be viewed as complementary to hard law. An understanding of soft law renews our optimism about what is possible in global health law, as using soft law offers a quick and flexible way to mobilize the consent and commitment of states in a rapidly changing environment with multistakeholder involvement.

Note

The authors have no conflicts of interest to declare.

\section{References}

1. L O. Gostin and A. L. Taylor, "Global Health Law: A Definition and Grand Challenges," Public Health Ethics 1, no. 1 (2008): 53-63, at 55 .

2. L O. Gostin and D. Sridhar, "Global Health and the Law," New England Journal of Medicine 370 (2014): 1732-1740.

3. C. Chinkin, "Normative Development in the International Legal System," in Commitment and Compliance: The Role of Non-Binding Norms in the International Legal System, D. Shelton, eds. (Oxford: Oxford University Press, 2000): 21-42.

4. B. M. Meier, A. Taylor, M. EcclestonTurner, R. Habibi, S. Sekalala, and L. O. Gostin, "The World Health Organization in Global Health Law," Journal of Law, Medicine $ซ 3$ Ethics 48, no. 4 (2020): $796-799$ 
5. D. P. Fidler, "The Future of the World Health Organization: What Role for International Law?" Vanderbilt Journal of Transnational Law 31, no. 5 (1998): 1079-1126.

6. The Union, "International Trade Agreements and their Impact on Tobacco Control: A Discussion Paper," Department for Tobacco Control, The International Union Against Tuberculosis and Lung Disease (2014): at 7, available at <https://theunion.org/ sites/default/files/2020-08/International_Trade_Agreements_and_their_ Impact on Tobacco_Control a Discussion_Paper.pdf $>$ (last visited February 2, 2021)

7. L. O. Gostin, R. Habibi, and B. M. Meier, "Has Global Health Law Risen to Meet the COVID-19 Challenge? Revisiting the International Health Regulations to Prepare for Future Threats," Journal of Law, Medicine $छ$ Ethics 48. no. 4 (2020): 376-381.

8. G. L. Burci, "The Legal Response to Pandemics," Journal of International Humanitarian Legal Studies 11, no. 2 (2020): 204-217, available at $<$ https:// doi.org/10.1163/18781527-01102003> (last visited February 2, 2021).

9. World Trade Organization (WTO), Doha declaration on the TRIPS agreement and public health, WT/MIN(01)/ $\mathrm{DEC} / \mathrm{W} / 2$. Ministerial conference (2001): Fourth Session, Doha, 9-14 November.
10. B. Toebes, "International Health Law: An Emerging Field of Public International Law," Indian Journal of International Law 55 (2015): 299-328, available at <https://doi.org/10.1007/ s40901-016-0020-9> (last visited February 2,2021 ).

11. See Gostin and Sridhar, supra note 2.

12. S. Sekalala, "Regime Shifting by MultiNational Corporations within Constitutional Courts in Developing Countries: Analysing Tobacco Litigation," Forthcoming.

13. J. Pauwelyn, R. A. Wessel, and J. Wouters, "When Structures Become Shackles: Stagnation and Dynamics in International Lawmaking," European Journal of International Law 25, no. 3 (2014): 733-763, available at <https:// doi.org/10.1093/ejil/chu051> (last visited February 2, 2021)

14. B. M. Meier, H. Huffstetler, and J. Bueno de Mesquita, "Monitoring and Review to Assess Human Rights Implementation," Foundations of Global Health $\&$ Human Rights, eds. L. O. Gostin and B. M. Meier (2020): 155-176.

15. S. L. Murthy, "Translating Legal Norms into Quantitative Indicators: Lessons from the Global Water, Sanitation, and Hygiene Sector," William छ Mary Environmental Law and Policy Review 42, no. 2 (2018): 385-446, available at <https://scholarship.law.wm.edu/ wmelpr/vol42/iss $2 / 2>$ (last visited February 2, 2021).

16. Pauwelyn, supra note 13.

17. See Burci, supra note 8.

18. A. L. Taylor and R. Habibi, "The Collapse of Global Cooperation under the WHO International Health Regulations at the Outset of COVID-19: Sculpting the Future of Global Health Governance," American Society of International Law-Insights 24, no. 5 (2020), available at <https://www. asil.org/insights/volume/24/issue/15 collapse-global-cooperation-underwho-international-health-regulations > (last visited February 2, 2021).

19. See Sekalala, supra note 12.

20. See Meier et al., supra note 4.

21. A. Kamradt-Scott and K. Lee, "The 2011 Pandemic Influenza Preparedness Framework: Global Health Secured or a Missed Opportunity?” Political Studies 59 (2011): 831-847.

22. T. A. Ghebreyesus, "WHO DirectorGeneral's Opening Remarks at the World Health Assembly," May 18, 2020, available at <https://www.who. int/director-general/speeches/detail/ who-director-general-s-openingremarks-at-the-world-health-assembly> (last visited February 25, 2021.) 